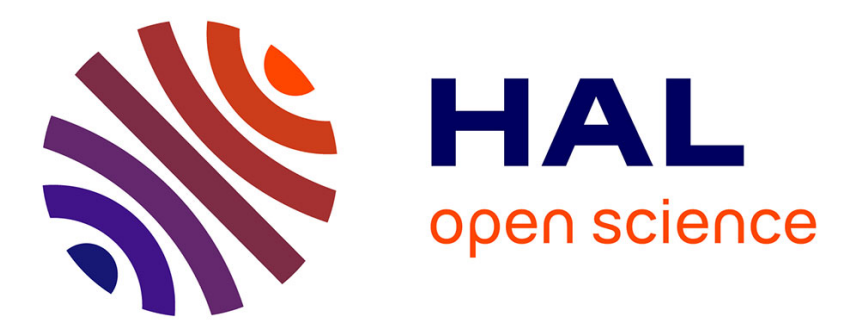

\title{
Changes in Family Situations as Reflected in the French Censuses, 1962-2009 \\ Laurent Toulemon
}

\section{To cite this version:}

Laurent Toulemon. Changes in Family Situations as Reflected in the French Censuses, 1962-2009. Population (English edition), 2012, The Demographic Situation in France, 67 (4), pp.551-572. hal03263273

\section{HAL Id: hal-03263273 \\ https://hal.science/hal-03263273}

Submitted on 17 Jun 2021

HAL is a multi-disciplinary open access archive for the deposit and dissemination of scientific research documents, whether they are published or not. The documents may come from teaching and research institutions in France or abroad, or from public or private research centers.
L'archive ouverte pluridisciplinaire HAL, est destinée au dépôt et à la diffusion de documents scientifiques de niveau recherche, publiés ou non, émanant des établissements d'enseignement et de recherche français ou étrangers, des laboratoires publics ou privés. 


\section{Laurent TOULEMON*}

\section{Changes in Family Situations as Reflected in the French Censuses, 1962-2009}

As the population censuses show, the average household size in France has decreased steadily over the past 50 years. There are fewer complex households (comprising members other than parents and their children) and more oneand two-person households (Daguet, 2007; Breuil-Genier, 2012). This trend is driven by changes in aspects of family behaviour such as the age of departure from the parental home, union formation, births, separations, departure of adult children, widowhood, etc. The change in population structure, notably the increasing share of older adults, has also contributed in recent years to the decrease in household size. The main aim of the census is to count the number of inhabitants (to estimate de jure populations) and to describe the size and structure of local populations on the basis of simple characteristics (sex, age, employment status, place of work or study) that provide useful information for local management of their needs. But the census is also the primary data source used by the French National Institute of Statistics and Economic Studies (INSEE), to describe family situations at local and national levels.

After describing the family situations of the French population as observed in the 2009 census, this article presents developments over the past 40 years by systematically comparing family situations by sex and age recorded in three censuses spaced around 20 years apart: 1968, 1990 and 2009. This comparison is based on harmonized data drawn from these censuses, constructed for metropolitan France (mainland France and Corsica).

Some family situations are poorly identified by the census, whose main purpose is to count the number of occupants in each dwelling. We show how these situations can be described more accurately, either in the census itself or in more detailed surveys. Finally, the advantages of the census based on rolling annual surveys are discussed.

\footnotetext{
* Institut national d'études démographiques, Paris.

Correspondence: Laurent Toulemon, Institut national d'études démographiques, 133 boulevard Davout, 75980 Paris Cedex 20, France, Tel: +33 (0)1 560621 16, e-mail: toulemon@ined.fr
} 


\section{Annual census surveys}

Since 2004, French census data have been collected through annual surveys. Under this rolling census system, the "census" is based on an aggregated set of five annual surveys dated for the median year. Every five years, all of the municipalities with a population under 10,000 - representing around half of the total resident population - are exhaustively surveyed, along with at least $40 \%$ of dwellings in municipalities with a population over 10,000 (8\% each year). The results of the "primary analysis" of all collected census forms are therefore based on a sample of around $70 \%$ of dwellings, aggregated under the median census year. The first complete results of the new census were therefore dated 2006 and were based on the samples of the 2004-2008 survey rounds. The construction of family categories within households and the coding of occupations is performed for only a portion of the households surveyed: onequarter in small municipalities, and the whole sample in large municipalities, i.e. roughly one-third of all households. This "complementary analysis" is performed at the same time as the primary one, enabling INSEE to release results at different geographical levels in the second half of every year $n$. The results are dated $n-3$ and are based on annual surveys conducted in the years $n-5$ to $n-1$ (Lefranc, 2010). The most recent complete results are therefore dated 2009 (based on annual surveys 2007-2011). Data at very different levels of detail (key figures showing simple results, detailed tables with cross-tabulation of data, and microdata files containing individual data) are available on INSEE's website, along with their documentation (INSEE, 2013).

\section{Population enumerated in households, then grouped into families}

When the census is taken, individuals are grouped into households, corresponding to dwellings that are "the household's primary residence". Within these households, the list of usual dwelling occupants serves to identify those who must be enumerated and fill out a census form. Other persons in the dwelling who usually reside elsewhere are not surveyed in the dwelling but in their primary residence.

In accordance with United Nations recommendations that focus on nuclear families (United Nations, 2008), INSEE constructs family categories for household occupants. A family may comprise either a couple (two people of different sexes living in the dwelling and identified as a couple) and any of their children; or one adult and his/her children. Only the dwelling residents are used to construct family categories. The children must not themselves be "adults in a family", i.e. living in a partnership (under the census definition) and/or with children who live in the same dwelling. In a household where three generations cohabit - grandparents, parents and children - INSEE thus constructs two families: a couple without children (the grandparents) and a couple with children (the parents and their children). People who live alone in their dwelling or who live with relatives who form a separate family, are 
considered as "not in a family". For example, if a single grandmother lives in a dwelling with one child and one grandchild, she will be recorded as "not in a family", because her child is the adult in another family. Applying these conventions, a household can consist of zero, one or two families; each resident belongs to only one family and a resident who does not have a spouse or a child living in the same dwelling is considered to be "not in a family".

A share of the population does not live in ordinary households (Pirou et al., 2013). In 2009, the "non-household population" comprised 1.47 million people (very similar percentages of males and females: $2.4 \%$ and $2.3 \%$, respectively), the majority of whom were living in long-term care facilities (retirement or nursing homes) (Table 1). A slightly higher percentage of males than females live in other types of collective dwellings or are homeless (Marpsat, 1999).

Table 1. Distribution by sex of household and non-household populations by type of collective dwelling (\%)

\begin{tabular}{|l|c|c|c|}
\hline & Males & Females & Total \\
\hline Household population & 97.57 & 97.72 & 97.65 \\
Non-household population, of which: & 2.43 & 2.28 & 2.35 \\
Medium- or long-term care facility & 1.29 & 1.66 & 1.48 \\
Religious community & 0.03 & 0.08 & 0.06 \\
Military barracks & 0.17 & 0.02 & 0.10 \\
Collective student accommodation & 0.50 & 0.32 & 0.40 \\
Short-term welfare accommodation & 0.02 & 0.00 & 0.01 \\
Other type of community & 0.19 & 0.01 & 0.09 \\
Mobile (e.g. boat dwellers, homeless) & 0.23 & 0.18 & 0.21 \\
Total & 100 & 100 & 100 \\
\hline Total population (thousands) & 30,247 & 32,219 & 62,466 \\
\hline Source: INSEE, 2009 population census, primary analysis, www.insee.fr, Table P02, metropolitan France. \\
\hline
\end{tabular}

Most people living in households belong to a family: $28 \%$ as children and $51 \%$ as adults in a family (Table 2). A higher percentage of males than females live in a family, both as children and as adults with a partner. Women are more frequently lone parents (mothers in a lone-parent family): 6.1\% versus 1.3\%.

These gender differences can be attributed both to differences in total numbers of males and females and in their age structure (females are more numerous than males and older on average), as well as to age-specific family situations at each age, resulting from gender-differentiated family behaviour. In the total population of France, there were two million more females than males in 2009: 32.2 million versus 30.2 million. At birth, however, there are 105 boys for every 100 girls, and this sex ratio is maintained through childhood. After age 18, due to differential migration and mortality, the sex ratio declines, and from 25 onwards, it is practically balanced. At ages 40-60, the ratio gradually falls below one (95 men for every 100 women at age 60), dropping sharply to 50 men per 100 women by age 85 (Figure 1). 
Table 2. Population distribution by sex, family situation and type of household (\%)

\begin{tabular}{|l|r|r|r|}
\hline & Males & Females & Total \\
\hline Child in a family & 30.94 & 25.42 & 28.09 \\
Child of a couple & 24.33 & 20.26 & 22.23 \\
Child of a lone parent & 6.61 & 5.16 & 5.86 \\
\hline Adult in a family & 50.44 & 52.27 & 51.38 \\
Adult in a partnership without children & 24.28 & 22.79 & 23.51 \\
Adult in a partnership with children & 24.88 & 23.35 & 24.09 \\
Adult in a lone-parent family & 1.28 & 6.13 & 3.78 \\
\hline Not in a family & 18.63 & 22.31 & 20.52 \\
Not in a family in a multi-person household & 3.76 & 3.61 & 3.68 \\
Alone in a single-person household & 12.46 & 16.44 & 14.51 \\
Not in an ordinary household & 2.41 & 2.26 & 2.33 \\
\hline Overall & 100 & 100 & 100 \\
\hline Source: INSEE, 2009 population census, complementary analysis, www.insee.fr, calculation based on microdata \\
files, "mode of cohabitation" variable, metropolitan France. \\
\hline
\end{tabular}

Figure 1. Number of females per 100 males at each age

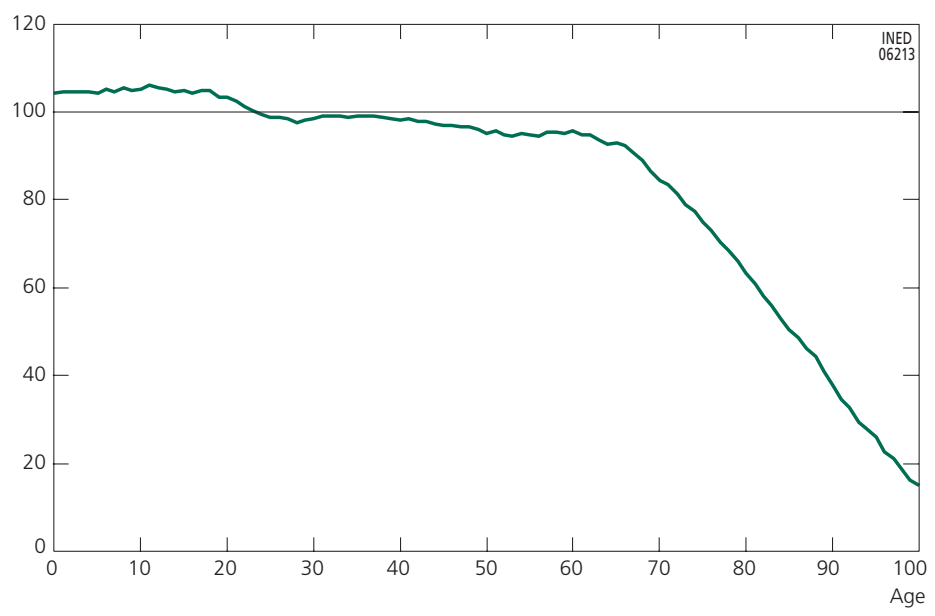

Source: INSEE, estimated population of France on 1 January 2009; Beaumel and Pla, 2011, Table 6, metropolitan France.

\section{Fewer children in families, more lone-parent families and more people living alone in the last $\mathbf{5 0}$ years}

\section{IPUMS-I data: harmonized, available and documented}

For previous censuses (back to 1962), the University of Minnesota's IPUMS-I project (Integrated Public Use Microdata Series International; McCaa et al., 2011) gives easy access to anonymous microdata files from complementary analyses, representing 5\% of the sample. 
In these files, the family relationships between dwelling occupants are recoded in a consistent manner. First, each individual's relationship with their spouse, father and mother (if they live in the dwelling) are identified. Other family relationships are then determined. Last, the family categories within households are constructed using these relationship variables (Sobek and Kennedy, 2009). These same categories are used for all countries included in the IPUMS-I programme. They are not identical to those used by INSEE, but the resulting household structure is very similar to the results published by INSEE for the 1990 and 1999 censuses, which are based on consistent definitions, notably without an age limit for being considered as a "child of the family" (INSEE, 2002, Table R14). The main difference concerns some cases of adults living in the same dwelling, considered automatically by INSEE as parent and child in a lone-parent family, and as "isolated not in a family" by the IPUMS-I variable. In 1990, the difference concerned 1\% of men and women, but in 1999 just $0.1 \%$ of women. The IPUMS-I data make it possible to apply the 2009 census definitions of age and family situations to the previous censuses (with a few exceptions, particularly students aged over 18 living away from home who are no longer enumerated with their parents; see Daguet, 2007).

The series of censuses since 1962 can be used to describe trends in male and female family situations over a period of roughly 50 years. The data were obtained from IPUMS-I for a research project on single-person households (Pennec and Toulemon, 2012). Table 3 shows the distribution of males and females by residential situation in the censuses from 1962 to 2009. The percentages of men and women living with a partner rose until 1982 and have declined since, although remaining relatively stable overall for half a century. Slightly under half of men (49\%) and women (46\%) lived with a partner in 2009. Between 1962 and 2009, the legal status of unions changed considerably, with a more than seven-point drop in the proportion of married people (from $47.8 \%$ to $40.2 \%$ for women, and from $45.1 \%$ to $37.6 \%$ for men; see Beaumel and $\mathrm{Pla}, 2011)$, although this was offset by the increasing proportion of persons in non-marital unions, which are more stable than in the past. The percentage of couples without children, stable at around 40\% between 1962 and 1982, has increased since then. This is attributable first to the delay in first births and their disconnection from union formation due to the spread of contraceptive use; and second, to a growing percentage of people living with a partner after their children have left home, thanks to declining mortality and widowhood. In $2009,53 \%$ of couples were not living with a child aged under 25 , compared with 40\% in 1962 and 41\% in 1982 (Daguet, 2007).

While the percentage of people living with a partner has remained stable, other family situations have changed substantially. Since 1968, the percentage of "children in a family" has decreased steadily, reflecting population ageing: the absolute number of persons aged under 25 has remained stable, at around 19 million, of which 17 million "children in a family" even though the population 
Table 3. Population distribution by sex, census year and residential situation (\%)

\begin{tabular}{|c|c|c|c|c|c|c|c|}
\hline \multirow{2}{*}{$\begin{array}{c}\text { Census } \\
\text { year }\end{array}$} & \multicolumn{7}{|c|}{ Residential situation at the time of the census } \\
\hline & $\begin{array}{c}\text { With } \\
\text { a partner }\end{array}$ & $\begin{array}{l}\text { Child in } \\
\text { a family }\end{array}$ & $\begin{array}{c}\text { Lone } \\
\text { parent }\end{array}$ & $\begin{array}{l}\text { Living alone } \\
\text { in dwelling }\end{array}$ & $\begin{array}{l}\text { Not in } \\
\text { a family }\end{array}$ & $\begin{array}{c}\text { Not in } \\
\text { a household }\end{array}$ & Overall \\
\hline \multicolumn{8}{|l|}{ Males } \\
\hline 1962 & 46.93 & 39.75 & 0.97 & 4.03 & 5.51 & 2.82 & 100 \\
\hline 1968 & 46.92 & 39.94 & 0.84 & 4.23 & 5.16 & 2.92 & 100 \\
\hline 1975 & 48.17 & 38.47 & 0.77 & 5.10 & 4.37 & 3.12 & 100 \\
\hline 1982 & 49.97 & 36.42 & 0.54 & 6.30 & 4.20 & 2.56 & 100 \\
\hline 1990 & 50.02 & 35.23 & 0.68 & 7.88 & 3.87 & 2.32 & 100 \\
\hline 1999 & 49.38 & 33.77 & 1.01 & 10.40 & 2.80 & 2.64 & 100 \\
\hline 2009 & 49.16 & 30.94 & 1.28 & 12.46 & 3.76 & 2.41 & 100 \\
\hline \multicolumn{8}{|l|}{ Females } \\
\hline 1962 & 44.35 & 34.01 & 3.51 & 8.17 & 7.87 & 2.08 & 100 \\
\hline 1968 & 44.60 & 34.22 & 3.24 & 8.54 & 6.94 & 2.45 & 100 \\
\hline 1975 & 46.23 & 32.82 & 3.15 & 9.77 & 5.63 & 2.40 & 100 \\
\hline 1982 & 47.62 & 30.42 & 3.04 & 11.37 & 5.35 & 2.20 & 100 \\
\hline 1990 & 47.44 & 29.29 & 3.89 & 12.63 & 4.63 & 2.12 & 100 \\
\hline 1999 & 46.79 & 27.57 & 5.52 & 14.62 & 3.14 & 2.37 & 100 \\
\hline 2009 & 46.14 & 25.43 & 6.13 & 16.44 & 3.61 & 2.26 & 100 \\
\hline
\end{tabular}

has grown from 49.8 million to 62.5 million (Chardon and Daguet, 2009; Beaumel and Pla, 2011). The percentage of children living in lone-parent families, consisting of one adult and his/her children, has increased sharply: in $2009,21 \%$ of children were recorded as living in the same dwelling as only one parent, up from 8\% in 1968 and 11\% in 1990 (Chardon et al., 2008). Loneparent families have also changed in nature: death of a parent is rarer, while divorces and separations have become more frequent. The percentages of lone parents declined between 1962 and 1982, to just 0.5\% of men and 3\% of women, but since then they have more than doubled. Simultaneously, the total percentage of people living in a family (whatever its composition), stable until 1982, has been falling since that date.

People not living in a family fall into one of three categories: people living alone in a single-person household; people living in a multi-person household but not in a family (either a household consisting of several "single" people not in a family, or a household of one or two families plus one or more individuals not in a family); and people not living in a household. The percentage of people living alone has increased substantially since 1962, and there are more women than men in this situation (16\% versus 12\%). In 1962, fewer people lived alone, and the gender gap was bigger, with twice as many women living alone as men ( $8 \%$ versus $4 \%$ ). The trend is symmetrical but downward for the percentage of people living in a household but not in a family: between 1962 and 2009, this 
situation became less common for both women (falling from 8\% to 4\%) and for men (falling from 6\% to 4\%) and the gender gap narrowed. A change in the definition of primary residence for young people explains the increases observed in 1999 and 2009. The percentage of males and females not living in a household remained stable at over $2 \%$.

Family situations vary considerably with age, and the variations by age can also be different for males and females (Beaumel et al., 2012). Although the distribution of family situations by age at a given date reflects family histories specific to each male and female cohort (Flipo et al., 1999), it is still useful for highlighting gender differences and changes over time from one census to the next.

\section{Very different family situations by gender and age}

In census-based family analysis, a couple consists of a man and a woman. There are therefore equal numbers of men and women living in partnerships. However, since there are more women than men, a higher proportion of men live with a partner. This is not true at young ages, and up to age 40 a higher proportion of women than of men live with a partner (Figure 2). When a union is dissolved by a death, it is more often the man who dies than the woman, and in cases of separation, men repartner more frequently and more rapidly than women. Overall, the proportion of men living with a partner increases until age 70 , when

Figure 2. Percentage of men and women in a partnership, and in a partnership with children, by age, in 2009

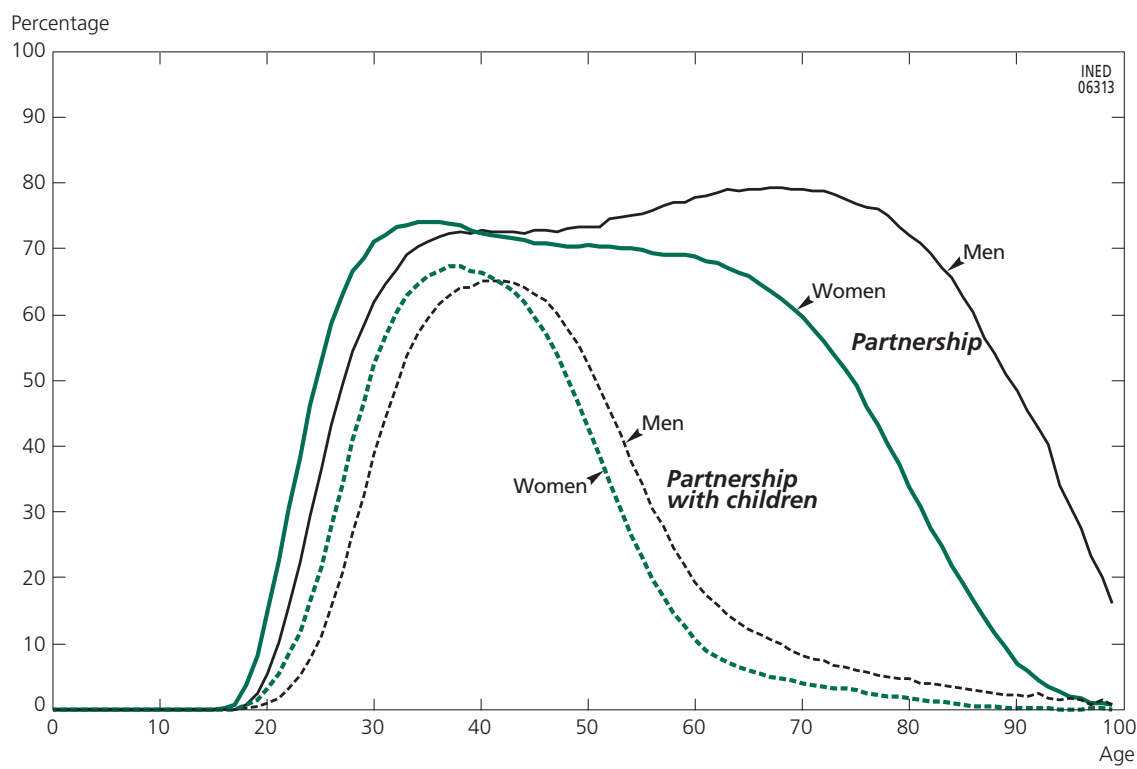

Source: INSEE, 2009 census, complementary analysis, www.insee.fr, calculation based on microdata files, "mode of cohabitation" variable, metropolitan France. 
four-fifths of men live with a partner, whereas the proportion of women living with a partner is highest (74\%) at age 35. A majority of young couples do not have children, and it is not until age 26 for women and age 28 for men that more than half of couples are living with a child. Among older couples, those without children again represent the majority, as their children have left home. At age 52 for women and 54 for men, more than half of couples are recorded as living without children. The share of couples with children then falls steadily with age.

Women less frequently live with a partner than men but, if we consider adults living in a family (with a partner or as lone parents), a higher proportion of women are recorded as adults in a family (Figure 3). After a separation, children usually live with their mothers. This explains why $16 \%$ of women are lone parents at age 45 , whereas less than $4 \%$ of men are lone parents at any age. After age 60, some lone parents live with their adult children. This situation is rare at age 70 (3\% of women and 1\% of men), but increases slightly at older ages, probably because some parents move in with their adult children after the death of their spouse. If the children in the dwelling are themselves single and childless, the elderly parent will be considered as the "adult in a family".

Figure 3. Percentages of men and women who are adults in a family, including with a partner or as lone parents, by age

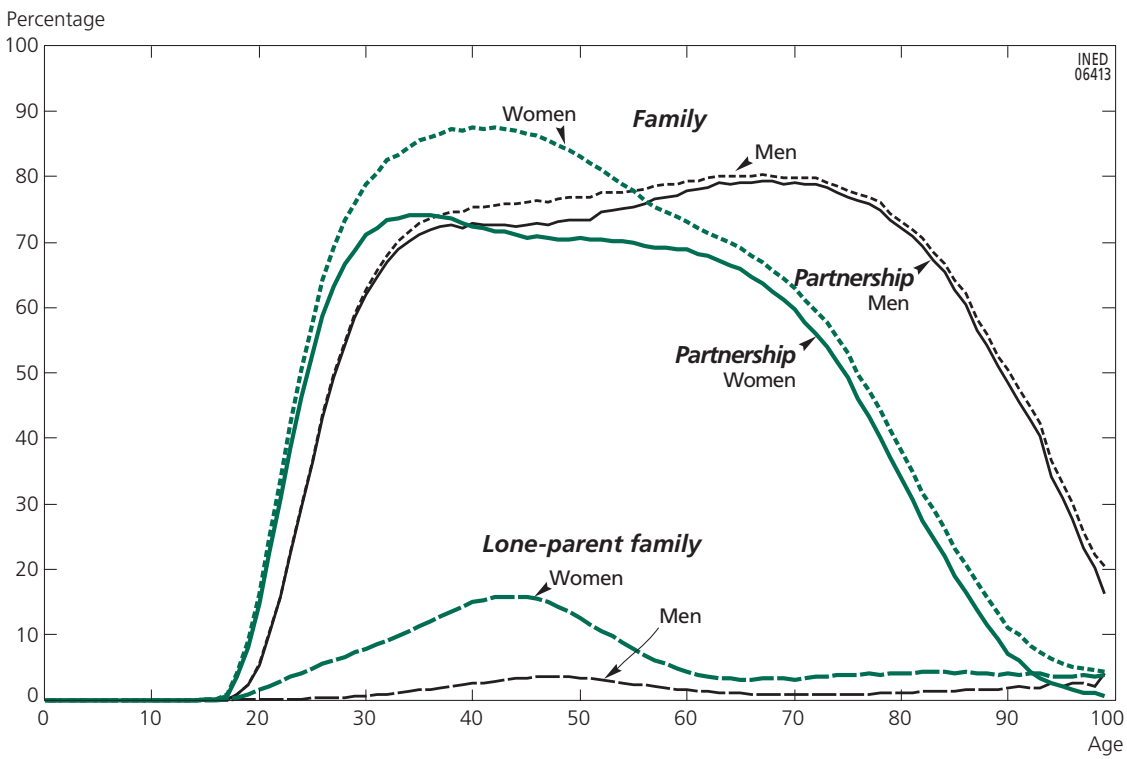

Source: INSEE, 2009 census, complementary analysis, www.insee.fr, calculation based on microdata files, "mode of cohabitation" variable, metropolitan France.

As to be expected, the proportion of children in a family decreases at the age when children leave their parents' home: at age 16, 97\% of young men and women are "children in a family" (Figure 4). At age 18, the percentages drop dramatically (74\% of men and 70\% of women), mainly because, in the 2009 
census, adult children who are studying away from home are recorded in the place where they live during the week, unlike children aged under 18. After age 18, men stay in their parents' home more frequently and for longer without themselves becoming "adults in a family". The gender gap at adult ages is striking: at age 35, 5.8\% of men are recorded as "children in a family", compared with only $2.3 \%$ of women. Among children, the percentage who live with one parent increases with age up to $25 \%$ at age 18 for both boys and girls. The percentage of children in lone-parent families in the general population thus peaks at age 16 (23\%) before decreasing steadily as children leave home. After age 60, the proportion of "children in a family" dwindles to almost zero. The proportion of very elderly parents of a family (with children who are themselves advanced in age) is not zero (see Figures 2 and 3) but, given the decrease in numbers with age, these proportions are negligible with respect to the total number of children.

Figure 4. Percentages of males and females who are children in a family, including in a lone-parent family, by age

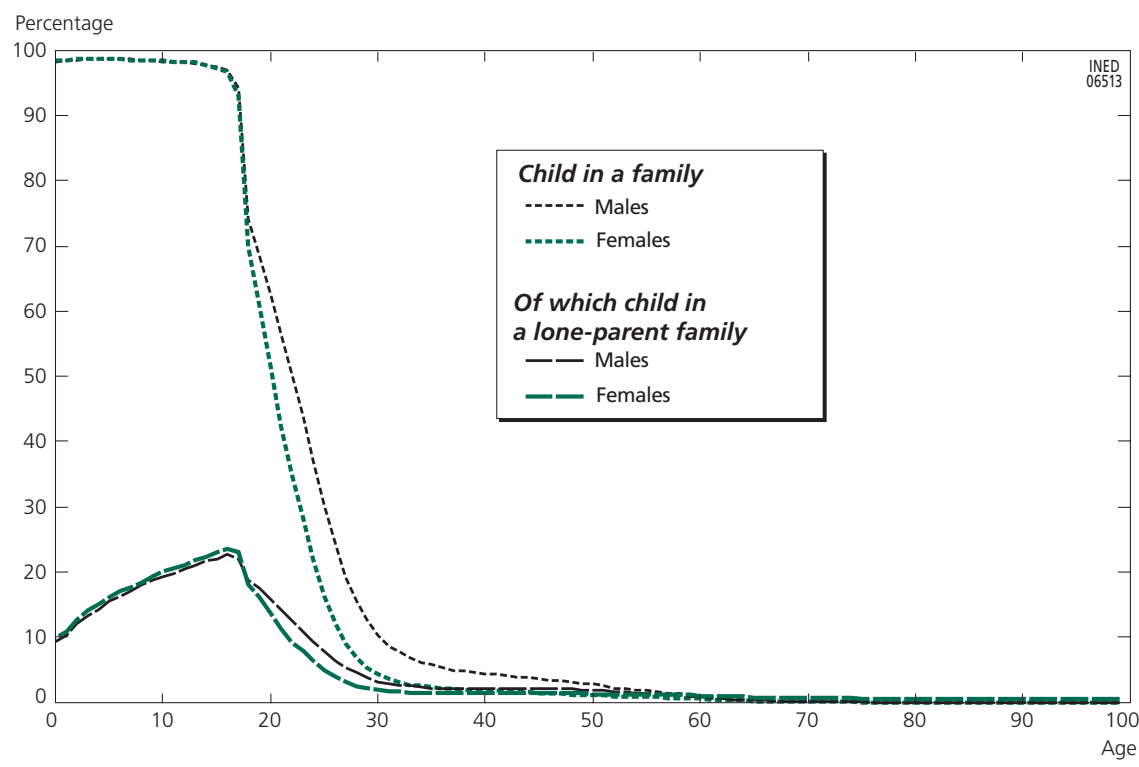

Source: INSEE, 2009 census, complementary analysis, www.insee.fr, calculation based on microdata files, "mode of cohabitation" variable, metropolitan France.

Most people who are not recorded in a family live alone in their dwelling (Table 2). The percentage of women living alone varies strongly with age. In early adulthood, in the interval between leaving her parents' home and forming a union, almost one woman in five lives alone (19\% at ages 21 and 22). At adult ages, very few women live alone (fewer than $8 \%$ at age 40 ), because when couples separate most children stay with their mothers. Subsequently, as children leave home and, in later years, as their partners die, the percentage of women living alone increases rapidly with age ( $56 \%$ by age 85$)$. After age 85 , 
problems of old-age dependence prevent many old women from living alone at home, and the most elderly women live in retirement homes (Figure 5). For men, the differences by age are much less pronounced: at adult ages, the percentage of men living alone never falls below 15\%, as men tend to live alone after a marital breakdown. After age 70 the percentage increases, but does not decrease in very old age as it does for women. The gender differences are similar for the situations "not in a family" and "not in a household", which are more frequent for men at adult ages, and more frequent for women in old age.

Figure 5. Percentages of males and females recorded as living alone, not in a family (in a household) or not in a household, by age

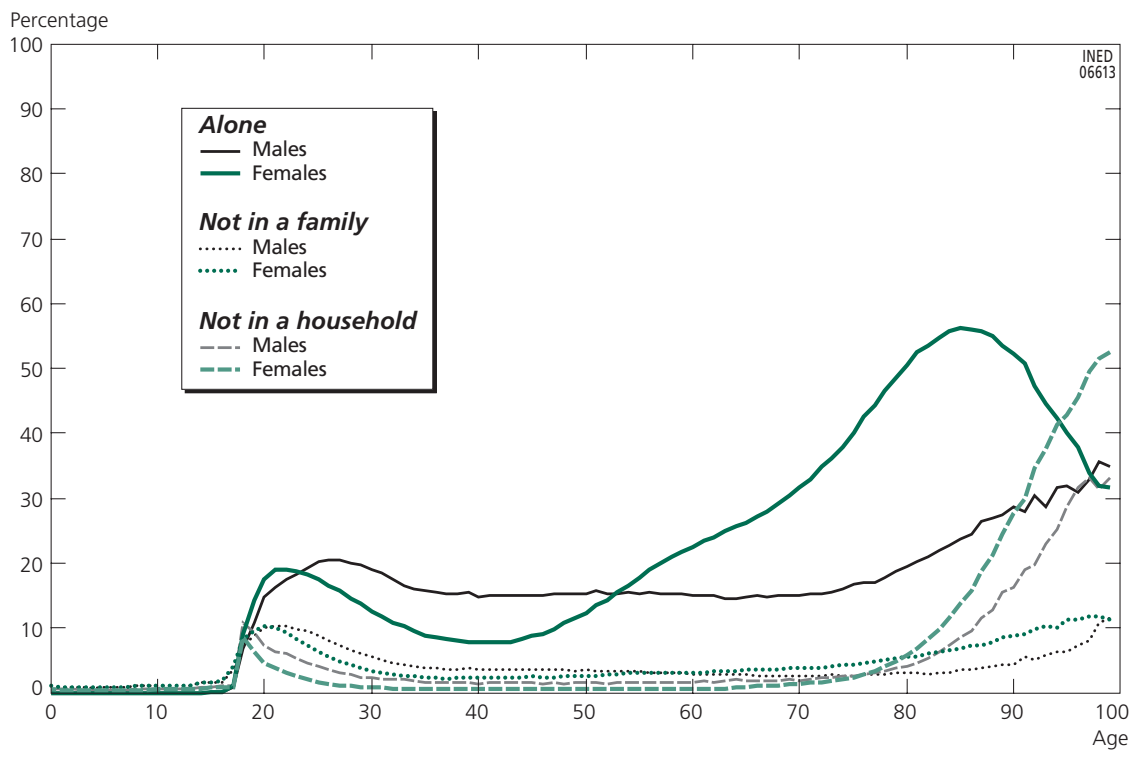

Source: INSEE, 2009 census, complementary analysis, www.insee.fr, calculation based on microdata files, "mode of cohabitation" variable, metropolitan France.

\section{Situations have changed differently} at each age over the past 40 years

The trends in family situations vary with age. Moreover, the age-specific changes over the past 40 years are also gender-specific. This can be seen in Figures 6 and 7, which show the percentages of males and females in different family situations at each age in the 1968, 1990 and 2009 censuses.

\section{Living with a partner}

The stable overall percentage of men and women living with a partner observed above (Table 3 ) results from a strong decrease at adult ages, offset by an increase in old age (Figures 6A and 6B). For both men and women, delayed first union formation and an increase in separations have reduced the frequency 
of living with a partner, especially from 1990 onwards. Since 1999, however, the proportion of young people aged 20-24 living with a partner has levelled off (Daguet and Niel, 2010). Mortality decline is delaying widowhood, as testified by a sharp increase in the percentages of men, and especially of women, living with a partner after age 80 .

\section{Not living with a partner}

The trend in lone-parent families is also strongly differentiated by gender and age: before age 50, the rise in separations is reflected in an increase in the percentage of lone mothers. The increase in lone fathers is very small because after a separation, men less frequently live with their children, while those who have custody of their children tend to form new unions sooner than lone mothers (Figures 6C and 6D). After age 50, there is an initial fall in the percentage of lone parents living with their adult children (considered as "children in a family" because they do not live with a partner or with their own children), characteristic of a general trend away from co-residence between older parents and their adult children. Over the past few decades, however, the pattern has reversed for lone mothers aged 60-80, as more single women in this age group are living with their single adult children. This trend is consistent with a tendency observed among men aged 40-50, more of whom were recorded as "children in a family" in 2009 than in 1990. Since the status of "child in a family" is almost entirely determined by age, the changes over the decades are very small for both males and females, except for a decline in the percentage of young adults aged 18-20 classed as "children in a family", which can be attributed to a change in the convention applied to students living away from home during the week (Figures 6E and 6F). More people aged 16-17 were living with their parents in 1990 than in 1968, due to the spread of secondary education; the slight increase in the percentage of men aged 40-50 recorded as "children in a family" is not observed for women. After a marital separation, a man who returns to live with his parents is recorded as a "child" if his own children are not recorded as living with him (because they are living with their mother), while his former partner will be recorded as the adult in a loneparent family if she lives with her children.

\section{Living alone}

The increase in the percentage of people living alone in a dwelling is most pronounced at around age 20 , for both men and women, because living in a separate dwelling is now a common stage in residential emancipation after leaving the parental home and before entering a union (Figures 7A and 7B). More elderly people are now living alone too, with the biggest change occurring between 1975 and 1982: the introduction of a minimum state old-age pension and improved health in old age have made it possible for old people to remain in their own homes after the death of their spouse. Between 1990 and 2009, the biggest increase in persons living alone concerned old women - who now 
Figure 6. Percentages of males and females, by age, recorded as in a family with a partner, as a parent in a lone-parent family, as a child in a family,

1968,1990 and 2009
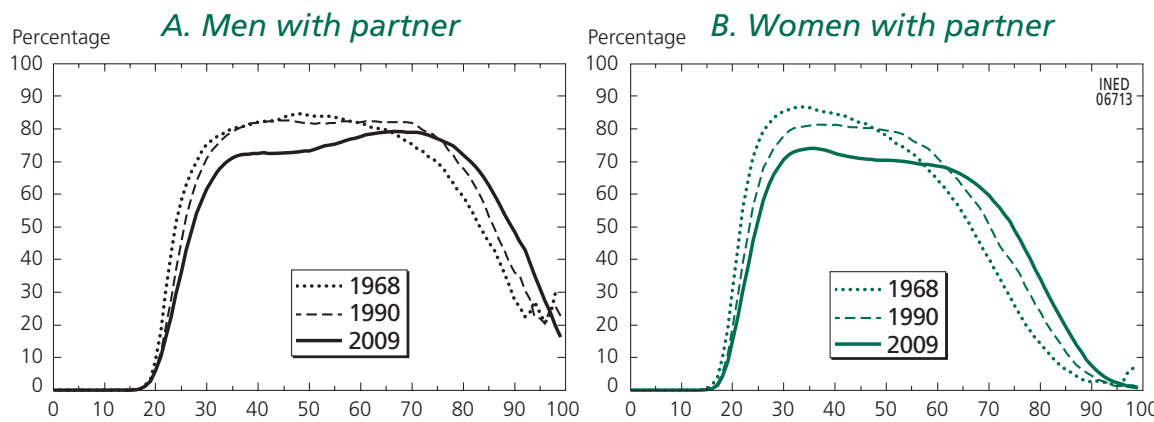

\section{Fathers without a partner}

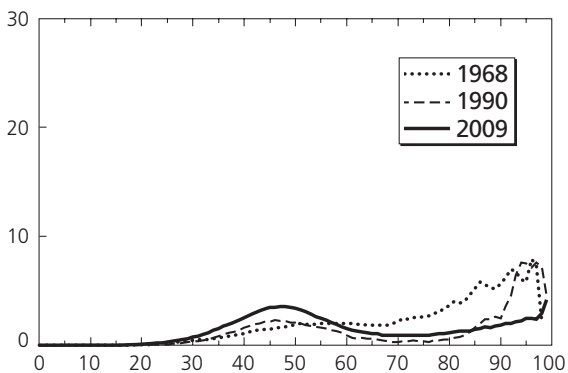

D. Mothers without a partner

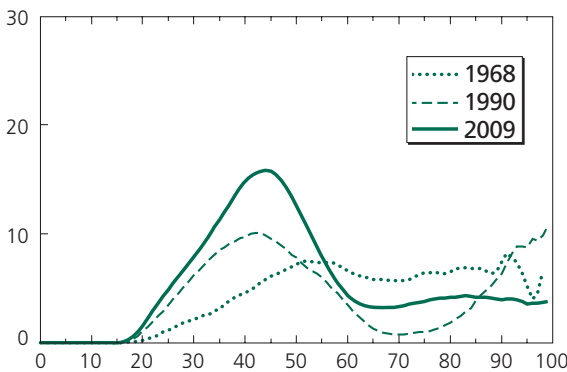

E. Males, children in a family

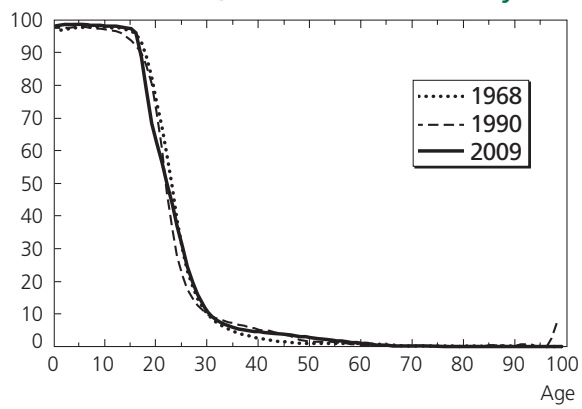

F. Females, children in a family

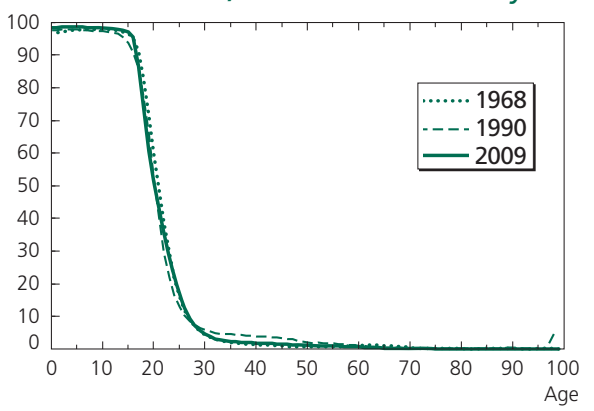

Coverage: Metropolitan France. Smoothed data, moving averages over three ages.

Sources: INSEE, censuses from 1962 to 2009. Calculations based on microdata files (complementary analysis): 1962-1999 - IPUMS-I data, Minnesota Population Center, Integrated Public Use Microdata Series, International. Minneapolis, University of Minnesota, 2011. 2009 - INSEE website, www. insee.fr.

more often stay in their own homes after widowhood - and adult men, who are more often alone after a marital separation or a divorce. In 1968, a large percentage of old people were recorded as "not in a family", although they shared a dwelling with relatives; these were elderly parents who lived with their adult children, often after the death of their spouse (Figures 7C and 7D). Such inter-generational co-residence reflected the limited autonomy of elderly 
Figure 7. Percentages of males and females, by age, recorded as not in a family (in a household), not in a household, or living alone, 1968, 1990 and 2009
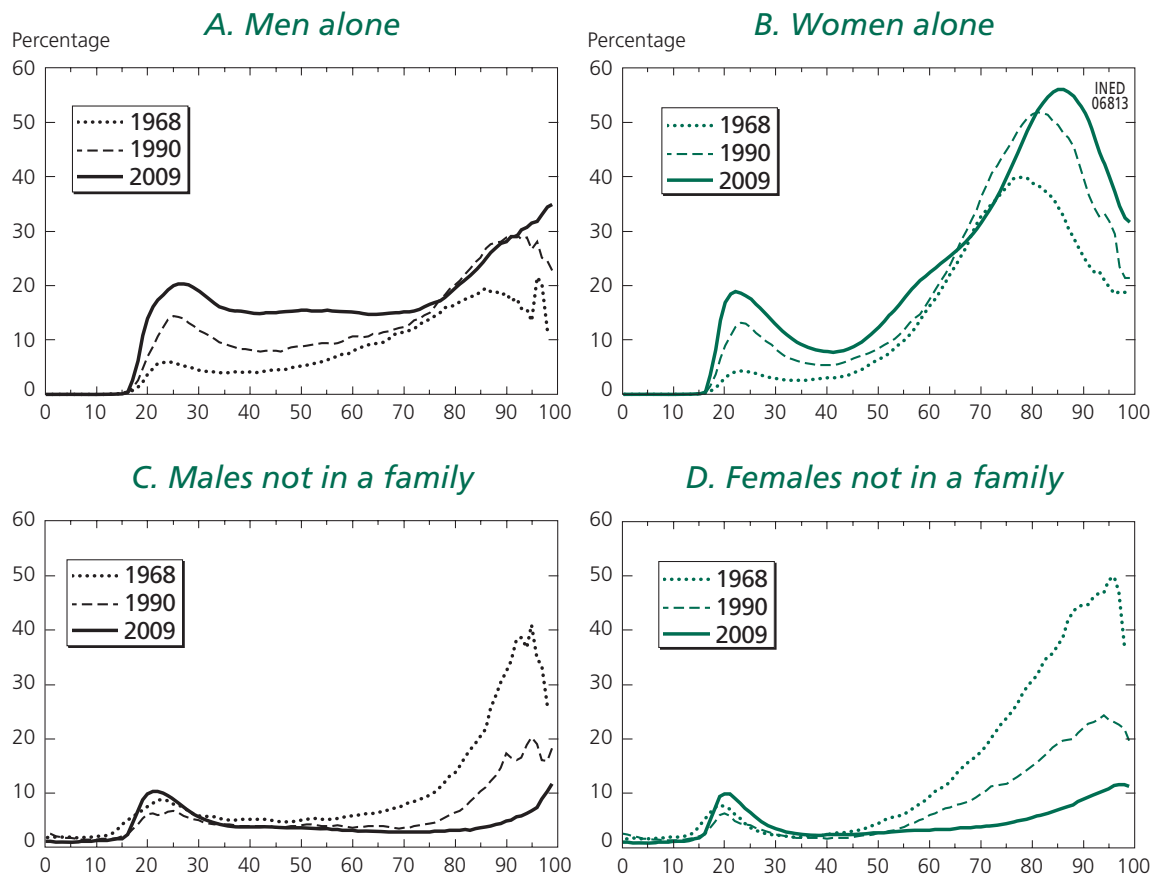

E. Males, not in a household

F. Females, not in a household
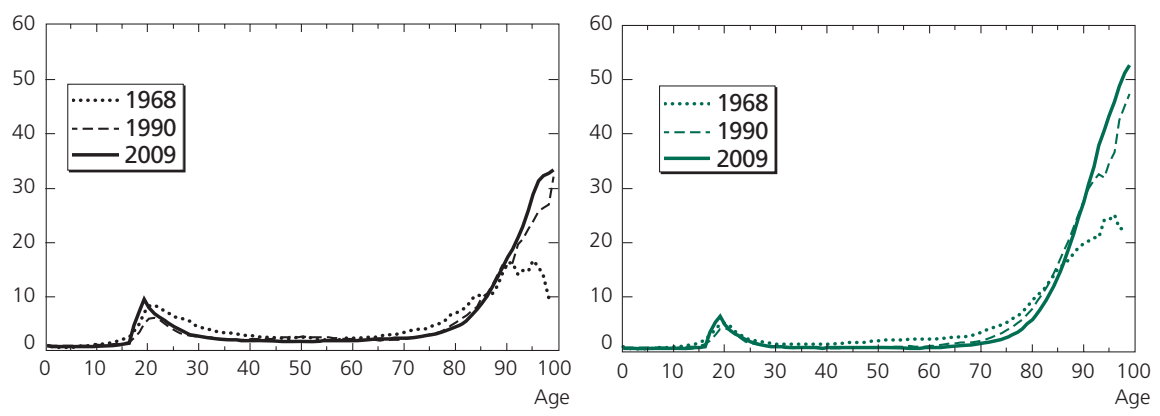

Coverage: Metropolitan France. Smoothed data, moving averages over three ages.

Sources: INSEE, censuses from 1962 to 2009. Calculations based on microdata files (complementary analysis): 1962-1999 - IPUMS-I data, Minnesota Population Center, Integrated Public Use Microdata Series, International. Minneapolis, University of Minnesota, 2011. 2009 - INSEE website, www.insee.fr.

people, in both financial and health terms; beyond age 80, older adults moved from living alone to sharing a home with the family. Forty years later, this situation is no longer characteristic of old age. After age 60, both men and women tend to live with a partner more often than before, and after age 70 they more often live alone. For young people, it is more common to live in a dwelling other than their parents' home (especially as students over age 18 are 
no longer recorded as living with their parents if they only return there at weekends), and home-sharing with non-relatives is becoming more widespread.

\section{Living in a collective household}

In the 2009 census, more people aged 18-19 were recorded as "not in a household", and fewer people aged under 85 were living in a retirement home (Figures 7E and 7F). In 2009, old people live with a partner up to more advanced ages than in 1968. After their spouse's death, they live alone more often and far less frequently with relatives, and the move into a retirement home occurs at older ages. Overall, no increase in the percentage of people living in collective households is observed, despite population ageing.

\section{Family situations and sociodemographic characteristics}

Although family ties are described in a simplified manner in the census, the population breakdown by "mode of cohabitation" proposed by INSEE does highlight key trends in family situations. Those trends are differentiated by age. There has been a decrease in living with a partner at adult ages and a corresponding increase in living as a lone parent for women and in living alone for men. Living with a partner and living alone in old age have increased, as reflected in the large decrease in co-residence with adult children or other relatives and the postponement of institutionalization. The lower percentage of the population recorded as "children in a family" can be attributed mainly to the changing age structure of the population, as people under 20 accounted for one-third of the population in 1968 but only one-quarter in 2009.

Those results can be broken down by various socio-demographic variables - such as educational level, employment status and socio-occupational category, urban or rural residence - to describe trends in family situations within different social groups. In most cases, strong interactions with gender and age emerge. As seen above, certain family situations have become more common for men or women at different ages. Similarly, differences by educational level, place of residence and occupation are often opposite for men and women, or vary across age groups. This can be illustrated by several examples from recent INSEE publications. The most educated women (with a degree in higher education) live with a partner less frequently before age 30 and after age 40 than other women, but - a new development in 2009 - more frequently at ages 30-40 (Daguet and Niel, 2010). Regarding men, contrasts by educational level have been very stable from one census to the next. There is little difference between men of different educational levels in terms of living with a partner, except at ages 30-50, when the most educated men slightly more frequently live with a partner. The increase in the proportion of women living alone before age 60 is observed across all social groups, except among women with a higherlevel or intermediate occupation, more of whom were living with a partner in 2009 than in 1990 (Buisson and Daguet, 2012). The percentage of women living 
as lone parents increased most among the least educated women: in 1990, 8\% of women aged 30-60 were recorded as adults in lone-parent families; in 2009, the percentage ranged from 14\% for the women with the lowest educational level (primary or less) to $10 \%$ for women with a higher education degree (Prioux et al., 2010, Albouy and Breuil-Genier, 2012). In 2009, the most educated women more often live alone than the least educated women, and less often in a loneparent family.

At young ages, the most educated men and women more often live alone, but at advanced ages (after age 70) the pattern reverses for women (the most educated women less often live alone and more often in a retirement home), whereas for men there is no apparent difference in living alone by educational level after age 40 . The same applies to differences by place of residence. Women living in rural areas live alone less often than urban women at every age, whereas for men this is only the case at young ages. Young people live "not in a family" more often in urban areas than in rural areas, whereas the pattern reverses after 60 for both men and women (Pennec and Toulemon, 2012). These interactions reflect the variety of family situations identified in the census, and their different significations by sex and age.

\section{Advantages and drawbacks of the census}

Having described family situations in France based on census data, we will now briefly review the advantages and drawbacks of the census, some of which are related to the new data collection method.

\section{An abundance of recent, easily accessible data}

The census results released by INSEE are detailed and precise. For the variables created in the "complementary analysis", such as "mode of cohabitation" mentioned above, the one-third population sample obtained by merging five annual surveys is larger than the one-quarter or one-fifth samples based on previous full censuses. INSEE's data dissemination policy, and respect for the anonymity of results and of microdata files limit the scope of certain analyses at local level, but the regional and national data are practically complete.

\section{Limited family information}

As for the former full census, census agents deliver the new census forms to dwellings for completion by household members and then return to collect them. The forms must be simple to ensure they will be understood and answered in the same way by all respondents. A delicate balance must be struck to ensure that the information provided by respondents is accurate: on the one hand, the question wording must be kept simple and the number of questions limited; on the other, a more specific question is sometimes easier to answer than a more general one, particularly when describing family relationships. Some 
questions need to be worded carefully to avoid confusion. For example, in the case of stepfamilies, which consist of a couple and children, at least one of whom is the child of only one of the adults in the couple, a distinction must be made between a "child" and a "stepchild" (or "partner's child").

Expanding the questions gives an indication of how imprecise the information may be. In 2004 a direct question about living with a partner was included in addition to legal marital status. In the 2009 census, 274,000 people were classed as "living with a partner" even though they answered "no" to the question "Do you live with a partner?" (Toulemon, 2011). In parallel, 938,000 reported living with a partner although they were not recorded as "living with a partner" in the household-families analysis. These differences can be explained by the large number of unclear or ambiguous situations (couples who own two dwellings, with each partner being recorded as not living with a partner in his/her "own" dwelling; same-sex couples not considered as couples under the census coding; and people who consider themselves as separated but who continue to live under the same roof) and by completion or data entry errors. The census also distinguishes between married and unmarried people, but for many years the answers were inaccurate because people who lived with a partner but were unmarried preferred to say they were married rather than "single, widowed or divorced" until a question about living with a partner, regardless of legal marital status, was introduced in 2004 (Audirac, 1986; Leridon and Villeneuve-Gokalp, 1989).

In addition, errors in completion, coding and data entry mean that special efforts must be made to identify rare situations, such as same-sex couples. Although errors of sex are very rare in the census, every such error concerning one member of a different-sex couple incorrectly creates a same-sex couple. As same-sex couples are rare in the population, many of the couples recorded as same-sex in the census are likely to be couples where the sex of one partner is wrongly filled in. For example, if there are 30 million people living with a partner, an error rate of $0.3 \%$ on the sex variable would result in the accidental creation of 90,000 same-sex couples in the data file. While that represents a tiny fraction of the 15 million couples, it is a very large inaccuracy with respect to the estimated number of cohabiting same-sex couples (between 30,000 and 100,000) (Digoix et al., 2004; Buisson and Lapinte, 2013).

These limitations are common to most censuses and call for two types of solutions. One is to complete the information by combining different sources. Olivier Chardon and Émilie Vivas did this to complete the census data on family situations: they used the Labour Force Survey to estimate the percentage of stepfamilies (couples living with at least one child born in a previous union) among families with children (Vivas, 2009). The other type of solution is to use other information sources, particularly household surveys, without seeking to achieve consistency with census data. Surveys record more co-resident couples than the census, for example. In 2009, the census identified a total of 
14.87 million couples, breaking down as 11.35 million married couples and 3.51 million unmarried couples (INSEE, 2009 census, FAM2 Table). According to the Labour Force Survey in 2008 and 2009, however, there were 15.37 million couples in total, including 3.61 million unmarried couples, i.e. 3\% more married couples and 3\% more unmarried couples than in the census. In the other INSEE surveys, the concept of "partnership" includes couples whose members do not share the same dwelling permanently and who may therefore be recorded in the census as living in separate dwellings. In general, couples who occupy two dwellings tend to report living in separate dwellings in the census, which leads to lower estimates of the frequency of living with a partner than in surveys. In many cases where a survey identifies a couple, the census classes people as living alone or in a lone-parent family, if the partner is recorded as living in another dwelling. Moreover, not all surveys produce identical results: the percentage of minor children living with their father without their mother is highly variable from one survey to another: a percentage of $2.5 \%$ was recorded in the Labour Force Survey, but in INSEE surveys that ask precise questions about situations of shared residence (although there are strong differences between surveys) $2 \%$ of children live with their father (without their mother) permanently, and 3\% some of the time only (Toulemon and Denoyelle, 2012). A systematic comparison of these surveys is needed before they can be analysed in a common dataset.

A growing diversity of family relationships is observed within co-residing households (stepfamilies, unmarried couples and same-sex couples) and an increase in situations where membership of a single household is ambiguous and difficult to establish: children dividing their time between two parental dwellings after their parents' separation (Toulemon and Pennec, 2010), young adults who have left their parents' home but who return there frequently, nonco-resident and partly co-resident couples (Régnier-Loilier et al., 2009), etc. These situations make it difficult for respondents to complete census forms based on a list of residents for whom the dwelling is their "primary residence" and that leave only a small space for "family relationship to the person indicated on the first line". Pending a revision of the census forms, the Family and Housing Survey conducted as part of the census survey in 2011 will provide more accurate information about family situations and multiple residences in a one-hundredth sample of the population (Rault et al., 2011).

\section{Double counts and omissions}

Every census suffers from double counts and omissions. The new census method, based on a regularly updated list of residential buildings and conducted by more "permanent" teams of census agents than in the past, has probably reduced the number of omissions. Conversely, there are probably more double counts of individuals who habitually live in more than one dwelling, because these dwellings are unlikely to be included in the same annual sample (Toulemon 
and Pennec, 2010; 2012). Moreover, there is no incentive for municipalities or INSEE to reduce double counts, because that would result in a smaller total population count. This problem is particularly visible in the number of 18-yearolds born in France, which is higher than the number of births 18 years earlier, despite deaths and emigration (Desplanques, 2008). No study on the scale of double counts and omissions in the new census has yet been published.

\section{Changes to the census form}

Making changes to the census forms is a long, costly operation. A working group of the statistical information council (Conseil national de l'information statistique, CNIS) recently submitted its proposals (Frécon et al., 2012). With the rolling annual census surveys, the aggregation of data collected over five years means that any change affects the production of results for four years. A question change in year $n$ will cause the information associated with that question to disappear from the files for four years (the four censuses dated from $n-2$ to $n+1$ that use data from the annual surveys both from year $n-1$ and from year $n$ ). For example, the replacement in 2011 of the question on "place of residence five years ago" with "place of residence one year ago" will make it easier to measure internal mobility and entries into France, but there are no published data on that question in the census results for 2009.

\section{Towards annual analyses?}

As all the results are published on INSEE's website, recent data can be accessed, and each round can be analysed separately (Desplanques, 2008; Davie and Mazuy, 2010; Davie and Niel, 2012). For analysis on a national or regional scale, the size of the annual samples (almost 9 million people, 4 million for the complementary analysis) and a balanced random sampling plan within each region guarantee the robustness of annual data, at least in structural terms, even if the annual coverage does not overlap exactly with that of the census, since certain population groups are not enumerated annually in large municipalities (homeless persons, mobile home occupiers). Concerning population size, it is difficult to follow changes from one year to the next since the total population is estimated by multiplying the number of dwellings by the number of people in each dwelling. In order to avoid collating the results from different years (the results dated 2009 correspond to data collected over the period 2007-2011), or to construct time series in which people only appear once, we could reweight each annual round so that it reflects the weight of the whole population on the date considered. There is still a need to verify that population changes from one year to the next are consistent with estimates of natural increase (births minus deaths) and net migration (entries minus departures), or to construct this consistency, for the total population and for any population sub-group, based on the series of annual samples. That could initially be done by comparing the "2006" population with the "2011" population, 
which have no common data collection year (2004-2008 and 2009-2013, respectively).

\section{Conclusion}

INSEE provides accurate, complete census results and very extensive datasets for analysis. Thanks to the datasets from previous censuses, we can describe trends in family situations in France since 1962, based on the conventions used to construct families in the census. The growing number of older couples resulting from the mortality decline counterbalances the effects of delayed first union formation and the increase in separations, so the percentage of people with a partner has remained constant. The increase in the share of people living alone corresponds to new stages of life, which differ by gender: more men live alone at adult ages after a marital separation, while more women live alone at old ages after widowhood. At old ages, the increase in the percentage of people living with a partner or alone in a single-person dwelling coincides with a sharp decrease in co-residence with adult children, and with the postponement of institutionalization. All these changes are shown here for the population as a whole, but the very large sample size provides scope for finer analysis which shows contrasting trends by social groups. For example, in 2009 the most educated women lived with a partner as frequently as other women; those not living with a partner more often lived alone and less often lived as lone parents than low-educated women. This type of trend results from changes in many behaviours, including union formation, birth of children, separation of couples with or without children, and repartnering. The census does not allow us to analyse the various stages that lead to particular family situations, but does provide an accurate overall picture.

The switch to rolling annual surveys makes it possible to monitor these developments. It offers new opportunities for data analysis, particularly through the separate analysis of each annual round, which will become essential if the content of the census forms is changed. It also provides an opportunity to conduct wide-ranging associated surveys to obtain additional information on smaller samples. 


\section{REFERENCES}

Albouy Valérie, Breuil-Genier Pascale, 2012, "Démographie et famille : les différences sociales se réduisent-elles?", France Portrait social - édition 2012, Paris, INSEE, pp. 11-18.

AUDIRAC Pierre-Alain, 1986, "La cohabitation : un million de couples non mariés", Économie et statistique, 185, pp. 13-33.

BEAUMEl Catherine, Pla Anne, 2011, "La situation démographique en 2009", Insee résultats, 122, Société.

Beaumel Catherine, Breuil-Genier Pascale, Daguet Fabienne, 2012, "Les âges de la vie : vingt ans d'évolutions". INSEE, Regards sur la parité, édition 2012, pp. 9-17. http://www.insee.fr/fr/ffc/docs_ffc/ref/FHPARIT12b_VElages.pdf.

BREUIL-GENIER Pascale, 2012, "Dix ans de recensement de la population. De plus en plus de petits ménages dans les régions", Insee première, 1410.

BUISSON Guillemette, DAGUET Fabienne, 2012, "Qui vit seul dans son logement? Qui vit en couple ?", Insee Première, 1392.

BUISSON Guillemette, LAPINTE Aude, 2013, "Le couple dans tous ses états. Non-cohabitation, conjoints de même sexe, Pacs...", Insee première, 1435.

Chardon Olivier, DaGUet Fabienne, 2009, "Enfants des couples, enfants des familles monoparentales. Des différences marquées pour les jeunes enfants", Insee première, 1216.

Chardon Olivier, Daguet Fabienne, Vivas Émilie, 2008, "Les familles monoparentales. Des difficultés à travailler et à se loger", Insee première, 1195.

DAGUET Fabienne, 2007, "Enquêtes annuelles de recensement de 2004 à 2006. Seul un tiers des ménages compte plus de deux personnes", Insee première, 1153.

DAGUET Fabienne, NiEL Xavier, 2010, "Vivre en couple. La proportion de jeunes en couple se stabilise", Insee première, 1281.

DAVIE Emma, MAzUY Magali, 2010, "Women's fertility and educational level in France: Evidence from the annual census surveys", Population, English Edition, 65(3), pp. 415-450.

DAVIE Emma, NiEL Xavier, 2012, "Mesurer et étudier la fécondité selon le rang de naissance: élaborer une statistique du nombre de naissances et d'âge à l'accouchement par rang", INSEE, Documents de travail, F1205.

http://www.insee.fr/fr/themes/document.asp?reg_id=0\&ref_id=F1205

DESPLANQUES Guy, 2008, "Strengths and uncertainties of the French annual census surveys", Population, English Edition, 63(3), pp. 415-440.

DigOIX Marie, FESTY Patrick, GARNIER Bénédicte, 2004, "What if same-sex couples exist in France after all?", in "Same-sex couples, same-sex partnerships and homosexual marriages: A focus on cross-national differentials", Paris, INED, Documents de travail, 124, pp. 193-210.

Flipo Anne, Le BlanC David, LAferrère Anne, 1999, "De l'histoire individuelle à la structure des ménages", Insee première, 649.

FrÉCON Jean-Claude, CASES Chantal, ClanchÉ François, OGER Pascal, 2012, Évolution du questionnaire du recensement de la population, Rapport d'un groupe de travail du Cnis, $\mathrm{n}^{\circ} 130,50 \mathrm{p}$.

http://www.cnis.fr/files/content/sites/Cnis/files/Fichiers/publications/rapports/2012/RAP_ 2012_130_evolution_questionnaire_recensement.PDF

INSEE, 2002, Recensement de la population de 1999 : tableaux thématiques, exploitation complémentaire, France métropolitaine. Ménages, familles, population totale. Paris : INSEE, $224 \mathrm{p}$. 
INSEE, 2013, Les résultats des recensements de la population. Le recensement de la population. http://www.insee.fr/fr/bases-de-donnees/default.asp?page=recensements.htm; http://www insee.fr/fr/publics/default.asp?page=communication/recensement/particuliers/accueil.htm

LEFRANC Christophe, 2010, "La diffusion des résultats du recensement rénové de la population", Courrier des statistiques, 129, pp. 1-6.

LeRIDON Henri, Villeneuve-GOKAlP Catherine, 1989, "The new couples: number, characteristics and attitudes", Population, An English Selection, 1, pp. 203-236.

MCCAA Robert, RugGLES Steven, SOBEK Matt, THOMAS Wendy, 2011, "IPUMS-International: Free, Worldwide Microdata Access. Now for Censuses of 62 Countries--80 by 2015”, 58th International Statistical Institute, Dublin, Ireland, 21-26 August, 2011,

http://www.hist.umn.edu/ rmccaa/sts065_ipums_international_future_microdata_access. pdf

MARPSAT Maryse, 1999, "An advantage with limits: the lower risk for women of becoming homeless", Population, An English Selection, 12, pp. 247-292.

PENNEC Sophie, TOULEMON Laurent, 2012, "How many people are living alone? How many are living in two dwellings? The case of France", European Population Conference, EAPS 2012, Stockholm, Session 38.

Pirou David, Poullain Nadine, Rochelle Sandrine, 2013, "La vie en communauté : 1,6 million de personnes en France", Insee Première, n 1434.

PRIOUX France, MAZUY Magali, BARBIERI Magali, 2010, "Recent demographic developments in France: fewer adults live with a partner", Population, 65 (3), pp. 421-474.

Rault Wilfried, Mazuy Magali, Rivière André, TOulEMON Laurent, 2011, "L'enquête Famille et logements associée au recensement de 2011" in Tremblay Marie-Ève, Lavallée Pierre, El Haj Tirari Mohammed, Pratiques et méthodes de sondage, Actes du colloque Sondages 2010, pp. 113-117.

RÉGnier-Loilier Arnaud, BEAujouan Éva, Villeneuve-Gokalp Catherine, 2009, "Neither single, nor a couple: A study of living apart together in France", Demographic Research, 21(4), pp. 75-108,

http://www.demographic-research.org/volumes/vol21/4/

SOBEK M., KENNEDy S., 2009, "The Development of Family Interrelationship Variables for International Census Data", Minnesota Population Center Working Paper Series, Working Paper 2009-02,

https://www.pop.umn.edu/research/working-papers.

TOULEMON Laurent, 2011, "Individus, familles, ménages, logements : les compter, les décrire", Travail, genre et sociétés, 26, pp. 47-66.

TOUlemon Laurent, PENNEC Sophie, 2010, "Multi-residence in France and Australia : Why count them? What is at stake? Double counting and actual family situations", Demographic Research, 23(1), pp. 1-40,

http://www.demographic-research.org/volumes/vol23/1/

TOUlEmOn Laurent, PENNEC Sophie, 2011, "How many people live alone in France?", Population and Societies, 484.

Toulemon Laurent, DenOyelle Thomas, 2012, "La définition des ménages dans les enquêtes françaises : comment tenir compte des multi-résidences ?", Présentation aux $X I^{e}$ journées de méthodologie statistique, Cité internationale universitaire de Paris, Session 26 : Collecte 3, janvier 2012. Publication électronique :

http://jms.insee.fr/files/documents/2012/943_3-JMS2012_S26-1_TOULEMON-ACTE.PDF.

United NATIONS, 2008, Principles and Recommendations for Population and Housing Censuses. Revision 2. Department of Economic and Social Affairs, Statistics Division. ST/ESA/STAT/ SER.M/67/Rev.2.

http://unstats.un.org/unsd/censuskb20/KnowledgebaseArticle10307.aspx

VIVAS Émilie, 2009, "1,2 million d'enfants de moins de 18 ans vivent dans une famille recomposée”, Insee Première, 1259. 


\section{Laurent TOULEMON • Changes in FAMily Situations as Reflected in the French CEnsuses, 1962-2009}

Censuses provide a means to count the population and to describe its main characteristics at all geographical levels. French census data from 1962 to 2006 are available via the IPUMS-I project of the University of Minnesota, and data for the years 2006-2009 are accessible on the INSEE website, so changes in family situations over the last fifty years can be described in detail. With the fertility decline and population ageing, the proportion of "children" has decreased. The other major changes (increasing share of persons living alone or in lone-parent families, fewer situations of co-residence with adult children or other relatives) follow very different patterns by sex and age. The same is often true for disparities between social groups (identified by occupational group, educational level or place of residence) and their evolution. The switch to annual census surveys in France provides new opportunities for analysing annual data, at least at national or regional scale, even though the census is designed to group the data from five successive annual waves.

\section{Laurent TOULEMON • ÉVOLUTION DES SITUATIONS FAMILIALES À TRAVERS LES RECENSEMENTS FRANÇAIS DE 1962 À 2009}

Les recensements permettent de compter la population et d'en décrire les principales caractéristiques à tous les niveaux géographiques. Grâce à la mise à disposition des données des recensements français, de 1962 à 2006 par le projet IPUMS-I de I'Université du Minnesota, depuis 2006 sur le site Internet de I'Insee, on peut décrire l'évolution des situations familiales depuis cinquante ans de manière très précise. La proportion $d^{\prime}$ "enfants" a diminué avec la baisse de la fécondité et le vieillissement de la population. Les autres changements majeurs (augmentation de la part des personnes vivant seules ou en famille monoparentale, stabilité de la proportion de personnes vivant en couple, raréfaction des situations de corésidence avec des enfants adultes ou des proches) se déclinent de façon très différenciées selon le sexe et l'âge. Les disparités entre groupes sociaux (repérés par la profession, le niveau de diplôme ou le lieu de résidence) et leurs évolutions sont elles aussi souvent fonction du sexe et de l'âge. Le passage à des enquêtes annuelles de recensement offre de nouvelles possibilités d'exploitation des données annuelles, au moins à l'échelle nationale ou régionale, bien que le recensement soit conçu comme le regroupement de cinq vagues annuelles.

\section{Laurent TOULEMON - LA EVOLUCIÓN DE LAS SITUACIONES FAMILIARES A TRAVÉS DE LOS CENSOS DE 1962 A 2009.}

Los censos permiten contar la población y describir sus principales características a todos los niveles geográficos. Los datos censales franceses de 1962 a 2006, disponibles gracias al proyecto IPUMS-I de la Universidad de Minnesota, prolongados por los de 2006 a 2009, accesibles en el sitio internet del INSEE, permiten describir de manera muy precisa la evolución de las situaciones familiares durante casi cincuenta años. La proporción de "niños" ha disminuido con la baja de la fecundidad y el envejecimiento de la población. Los otros cambios importantes (aumento de la proporción de personas que viven solas o en familia monoparental, estabilidad de la proporción de las que viven en pareja, rarefacción de las situaciones de cohabitación con hijos adultos o con parientes) varían fuertemente según el sexo y la edad. Las diferencias entre grupos sociales (distinguidos por la profesión, el nivel de diploma o el lugar de residencia) y su evolución son también frecuentemente función del sexo y la edad. El paso del censo tradicional a las encuestas censales de periodicidad anual ofrece nuevas posibilidades de explotación de los datos anuales, al menos a escala nacional o regional, aunque el censo esté concebido como el reagrupamiento de cinco oleadas anuales.

Keywords: Census, France, family situations, households, couple, parent, child.

Translated by Madeleine Grieve. 